\title{
XXXIII. A botanical description of Hermione Cypri
}

\section{A.H. Haworth F.L.S.}

To cite this article: A.H. Haworth F.L.S. (1831) XXXIII. A botanical description of Hermione Cypri, Philosophical Magazine Series 2, 9:51, 183-185, DOI: 10.1080/14786443108647584

To link to this article: http://dx.doi.org/10.1080/14786443108647584

册 Published online: 01 Jun 2009.

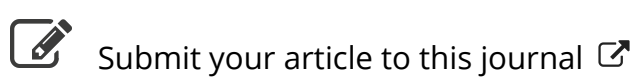

LII Article views: 1

Q View related articles $\sqsubset$ 
any two of the four places by the respective two numbers in parentheses, we have

$$
\begin{aligned}
& \left(\begin{array}{ll}
1 & 2
\end{array}\right)^{2}=\left(\xi_{2}-\xi_{1}\right)^{2}+\left(\eta_{2}-\eta_{1}\right)^{2} \\
& \left(\begin{array}{ll}
1 & 3
\end{array}\right)^{2}=\left(\xi_{3}-\xi_{1}\right)^{2}+\left(\eta_{3}-\eta_{1}\right)^{2} \\
& \left(\begin{array}{ll}
1 & 4
\end{array}\right)^{2}=\left(\xi_{4}-\xi_{1}\right)^{2}+\left(\eta_{4}-\eta_{1}\right)^{2} \\
& \left(\begin{array}{ll}
2 & 3
\end{array}\right)^{2}=\left(\xi_{3}-\xi_{2}\right)^{2}+\left(\eta_{3}-\eta_{2}\right)^{2} \\
& \left(\begin{array}{ll}
2 & 4
\end{array}\right)^{2}=\left(\xi_{4}-\xi_{2}\right)^{2}+\left(\eta_{4}-\eta_{2}\right)^{2} \\
& \left(\begin{array}{ll}
3 & 4
\end{array}\right)^{2}=\left(\xi_{4}-\xi_{3}\right)^{2}+\left(\eta_{4}-\eta_{3}\right)^{2}
\end{aligned}
$$

The equations (A) (B) (C) (D) contain the data of the observations.

[To be continued.]

XXXIII. A Botanical Description of Hermione Cypri. By A. H. H AworTH, F.L.S. \&;c. \&c.

To the Editors of the Philosophical Magazine and Annals. Gentlemen,

IN my last communication to your useful Magazine, N. S. vol. viii. p. 130, it was stated, under the description of Hermione tenuifiora, that the double and semi-double flowering varieties, hitherto proposed doubtingly under it, were probably of another and distinct species, supposed to come from the Island of Cyprus, which I there designated H. Cypri.

At that time the flowers, in their single state, had not fallen under my examination. In fact I never could procure or find the plant in that state until the present time; when the acute eye of my friend Mr. Sweet detected a specimen of it, nearly in full bloom, amongst Mr. Colvill's forced bulbs, at his noble Nursery in the King's Road; whither I went to examine it, and there saw along with other bulbous plants, in full bloom, the most showy and best managed collection of Hybrid Amaryllid I ever beheld.

I had no sooner pronounced the Hermione Cypri new to me, and to be undescribed, by any modern writer at least, in its single state, than Mr. Colvill, with his usual kindness towards belping me to elucidate this beautiful tribe of plants, made me a present of it; although it was the only one in his extensive collection.

I am the more flattered at this, because it enables me to show that the conjecture I made, as above cited, concerning the distinctness of this species, has not proved incorrect. And I hope to persuade $\mathrm{Mr}$. Sweet to give the botanical world a representation of it, from the pencil of his excellent artist Mr. Smith, in an early Number of his beautiful British Flower

Garden. 
184 Mr. Haworth's Botanical Description of Hermione Cypri.

Garden. I have carefully drawn up the following botamical description of $\boldsymbol{H}$. Cypri, for your Magazine; and remrain,

Gentlemen, yours, \&c.

\section{A. H. Hawori'r.}

Genus, Hermione Nob. in Narciss. Revis. p. 121.

\section{Sectio secunda Alвz.}

Cypri. H. (slender early white) scapo subquadrifloro, gracili; corollæ laciniis obovatis, mucronatis, subimbricantibus, semireflexis; coronâ cupulari luteâ, truncatâ, sesquiduplò longioribus.

N. Cypri Nob. in Phil. Mag. N.S. viii. 133-4.

Habitat in Insula Cypri.

Floret in caldario in Januario, sed in aëre aperto forsan in Martio.

Descriptio. Herba tunicatim bulbosa, subpedalis. Folia erecta, lorata, hujus generis ordinaria, supernè primò ferè plana, obtusa, viridia, post florescentiam longiora, obliquè flexa. Scapus gracilior quàm in affinibus proximis, striatus, virens, ferè solidus; basi teretiusculus, supernè sensim parùm compressus et anceps ; florendi tempore foliorum altitudine; demùm illis brevior, et supernè cavus. Spatha in exemplo nostro quadriflora, ordinaria, erecta, altitudine pedunculorum minorum. Pedunculi erecti, inæquales, 1-2-unciales, graciles, acutè triangulares, lætè virides, elevatìm striatuli, germine (florendi tempore) parvo, oblongo, obtusè triangulari, striatulo, saturatiore. Flores eleganter rectangulatìm nutantes, vel plùs; sed nunquam cernui : corolla, laciniźs obovatis vel oblongoobovatis seu ferè ellipticis albis, extùs basi luteis (interioribus minoribus, ut in omnibus et minùs mucronu. latis), tubo respectu primo ferè horizontalibus, planis, vel variè paululùm flexis et imbricantibus; demùm semireflexis, et variè flexuosim obliquis; tubo prismatico lætè viridi, gracili, parùm longioribus. Corona lutea, crassa, firma; ore integro, ruptatim subindè unifissa subregularis, et paulò latior quàm altior. Stamina ordinaria et pollen coronæ concolora, 3 interiora tubo humiliora; antheris ordinariis inclusis, tria alia tubi altitudine, antheris protuberantibus. Stylus gracilis, albicans, coronam rquans, stigmatibus tribus exiguis seu minimis, planis, patulis, subrotundis, albis.

Obs. N. Tazettæ Linn. in Fl. Grcec. tab. 308, pulcherrimè representata, simillima, ut ovum ovo; at 
differt bulbo triplo majore; scapo basi solidiusculo non cavo; foliis (in caldario) non glaucescentibus; planis, non flexulis, florum pedunculis acuto-triangularibus, non teretiusculis, laciniis corollæ valdè albis, nec lacteis; tubo parùm longioribus, nec tubi longitudine; coronấ luteâ, nec aurantiâ, sesquiduplò nec triplò longioribus, et lævi, non plicata, ut in $F l$. Graca supra citatâ.

B. semiplena. Park. Parad. 85. fig. 2.

\%. plena. Park. Parad. 85. f. 3. 4.

I dare not cite the beautiful tigure of $t a b .1011$, in the Botanical Magazine, there calledNarcissus orientalis, var. Fl. Pl., because that plant shows eight flowers on its slender scape, which in that respect very well agrees; but I much doubt whether ours would ever have more than four or five. But it may be the double state of N. Tazetta of Fl. Gr.l.c., as the latter is there said to bear, when cultivated, many flowers.

If this conjecture proves correct, it will afford another instance of extremely similar species often occurring, as it were, in pairs; as in H. pracox of Tenore; and H. tenuiflora Nob. H. papyratia, Bot. Mag. 947, and H. Jasminea Salisb. et Nob. and many others.

That zealous and indefatigable Botanical Professor Dr. Schultes, assisted by his son Dr. Schultes, have greatly aided my endeavours to elucidate the Narcissea, by completely copying the whole of my last contribution to your excellent Magazine, on these much favoured plants, into the Addenda at the end of the 7th volume of their new edition of Linn. Syst. $V$ eg. just published; which will doubtless spread the matter much more extensively than has hitherto been accomplished.

Chelsea, Feb. 7th, 1831.

XXXIV. On an Omission in Clairaut's Theory of the Equilibrium of a homogeneous Fluid; in some Remarks on the 56th Article of the "Bulletin des Sciences Mathematiques" for August 1830. By J AMEs Ivory, Esq. M.A. F.R.S.*

A $\mathbf{N}$ article in the Bulletin des Sciences Mathematiques for $A$ August 1830, demands some observations from me.

We may begin with stating, in what Clairaut's theory of the equilibrium of a homogeneous fluid consists. 'This is a point not in any respect doubtful. According to the inventor of the theory and all other authors, two conditions are necessary and sufficient for the equilibrium. Supposing the equilibrium possible, it gives only one equation for determining the figure of the fluid. No accelerating forces are taken into - Communicated by the Author.

N.S. Vol. 9. No. 51. Mar. 1831. 